\title{
Landfill Sitting by Two Methods in Al-Qasim, Babylon, Iraq and Comparing Them Using Change Detection Method
}

\author{
Ali Chabuk ${ }^{1}$, Nadhir Al-Ansari' ${ }^{1}$, Hussain Musa Hussain ${ }^{2}$, Sven Knutsson ${ }^{1}$, Roland Pusch1, \\ Jan Laue ${ }^{1}$ \\ ${ }^{1}$ Department of Civil Environmental and Natural Resources Engineering, Lulea University of Technology, Lulea, Sweden \\ ${ }^{2}$ Department of Geology, Faculty of Science, University of Kufa, Kufa, Iraq \\ Email: ali.chabuk@ltu.se,nadhir.alansari@ltu.se,humhudhy02@gmail.com,Sven.Knutsson@ltu.se, \\ drawrite.se@gmail.com,jan.laue@ltu.se
}

How to cite this paper: Chabuk, A., Al-Ansari, N., Hussain, H.M., Knutsson, S., Pusch, R. and Laue, J. (2017) Landfill Sitting by Two Methods in Al-Qasim, Babylon, Iraq and Comparing Them Using Change Detection Method. Engineering, 9, 723-737.

https://doi.org/10.4236/eng.2017.98044

Received: August 4, 2017

Accepted: August 27, 2017

Published: August 30, 2017

Copyright $\odot 2017$ by authors and Scientific Research Publishing Inc. This work is licensed under the Creative Commons Attribution International License (CC BY 4.0).

http://creativecommons.org/licenses/by/4.0/

\begin{abstract}
The selecting of a site for landfill is considered as a difficult process because many criteria should be involved. The main aim of establishing a landfill is to protect the human and environment. Al-Qasim district is considered as the study area in this work. It is one of the main districts in Babylon Governorate, Iraq. There is no systematic site as landfill that fulfil the environmental and scientific criteria in this area. Therefore, the most important fifteen criteria that suited the environmental requirements were selected in the current study. These criteria are: groundwater depth, urban centers, rivers, villages, soil types, elevation, roads agricultural land use, slope, land use, archaeological sites, power lines, gas pipelines, oil pipelines and railways. Two methods of multi criteria decision making AHP (analytical hierarchy process) and SRS (straight rank sum) were applied to obtain the weights of criteria in dissimilar styles. The raster maps of the selected criteria were prepared and analyzed within the GIS software. Then, the change detection method was implemented to compare the two output raster maps resulted from AHP and SRS methods. Two appropriate candidate sites for landfill were selected to accommodate the cumulative solid waste until the year 2030 in Qasim district. The areas of these sites were $2.766 \mathrm{~km}^{2}$ and $2.055 \mathrm{~km}^{2}$ respectively.
\end{abstract}

\section{Keywords}

Landfill Sites, Change Detection, AHP, SRS, GIS, Al-Qasim

\section{Introduction}

Solid Waste Management is considered a source of concern in developing coun- 
tries due to many factors, which effects on human health and environmental, where they arise from open dumping sites that are often commonly used in the disposal of waste randomly [1]. In developed countries, there are many processes to achieve a proper management for solid waste such as recycling, minimizing the waste, recovery of energy, reuse, and landfill [2]. Even if other techniques of waste management are used, a landfill site is considered very necessary to a solid waste management system to accommodate unused materials or the remains parts of waste that burn, because landfill is simple to use and relatively inexpensive [3] [4] [5]. Therefore, many previous studies were interested with the most details of landfill management within the last two decades, especially selecting an appropriate site for landfill [6] [7]. The selection site for landfill is considered one of the difficult processes related to solid Waste Management systems and a major concern for decision-makers and official authorities. This process is subjected to many factors and constraints such as government funding, government regulations, increasing population growth rate, growing environmental awareness, public health, protecting the environment, reductive of available land for landfills, improving standards of living and increasing political and social opposition to the landfill sites' establishment [8] [9].

Geographic information system (GIS) and multi-criteria decision making methods are represented powerful and integrated tools used to solve the problem of selecting sites for landfill. GIS plays an important role for selecting a site for landfill. It reduces time and cost in the process of landfill siting, as well as having a high capability to manage large volumes of data from variety of sources. Multi criteria decision methods (MCDA) often help decision-makers to handle the large amount of complex information [2] [10] [11]. Analytical hierarchy process (AHP) and SRS (straight rank sum) are considered as examples of such methods. AHP was developed originally by Saaty [12] in 1980 to derive the weights of criteria using pair wise comparison matrix. SRS is considered one of the multi criteria making methods, where this method was adopted on giving the weights for criteria directly [13].

In this study, the Change Detection method was used to compare two raster maps that were resulted from using the AHP and SRS methods, where this method was used to determine the pixels' percentage of matching and non-matching for two maps.

The main aim of this study is determined suitable candidate sites for landfill in Al-Qasim Qadhaa, Babylon Governorate, Iraq through using two methods of multi-criteria decision making (AHP and SRS) and GIS software. In addition, the resultant maps of two methods were compared using the Change Detection method to determine the proportion of areas for matching and non-matching.

\section{Methodology}

\subsection{Study Area}

Al-Qasim Qadhaa was formed newly and considered one of the five major cities 
of Babylon Governorate, Iraq. It is situated in the southern part of the Babylon Governorate. Al-Qasim Qadhaa includes two cities are Al-Qasim and Al-Talyaah. This Qadhaa occupies an area of $637 \mathrm{~km}^{2}$ [14]. It is located between longitude $44^{\circ} 27^{\prime} 41^{\prime \prime} \mathrm{E}$ and $44^{\circ} 49^{\prime} 24^{\prime \prime} \mathrm{E}$, and latitude $32^{\circ} 25^{\prime} 53^{\prime \prime} \mathrm{N}$ and $32^{\circ} 5^{\prime} 53^{\prime \prime} \mathrm{N}$ (Figure 1). The estimated population of Al-Qasim district was 201,664 inhabitants in 2016 with the annual population growth rate of $2.99 \%$ [15].

\subsection{Sources of Required Maps}

For preparing the required maps for this study, many sources were used for this purpose. One of these sources was as digital maps (shape files). These maps are: topography, slope, river, road, urban centers, villages, archaeological sites, gas pipelines, oil pipelines, power lines and railways, where these maps were adopted according to the internal reports of the Iraqi Ministry of Education [16]. The second source for preparing the required maps was the available data which was entered in GIS, where the readings of 170 wells for the depths of groundwater were entered into GIS to generate an interpolation between them using the spatial extension tool called Kriging in order to produce the digital map of groundwater depth in Al-Qasim Qadhaa [17]. The third sources which were used to produce the required maps in this study were the published maps. These maps were prepared within GIS using spatial analysis tools as a separate shape file using the relevant information in each map, and then they were converted to the digital maps. The digital map of "agricultural land" was determined using the published map of land capability of Iraq (scale 1:1,000,000) [18], and it was checked by analyzing satellite images of the Babylon Governorate from 2011 [19]. The digital map of "soil types" was obtained using the map of exploratory soil of Iraq was used (scale 1:1,000,000) [20]. The map of industrial areas (scale 1: 400,000) [14] shows industrial locations within this Qadhaa, while the map arc-

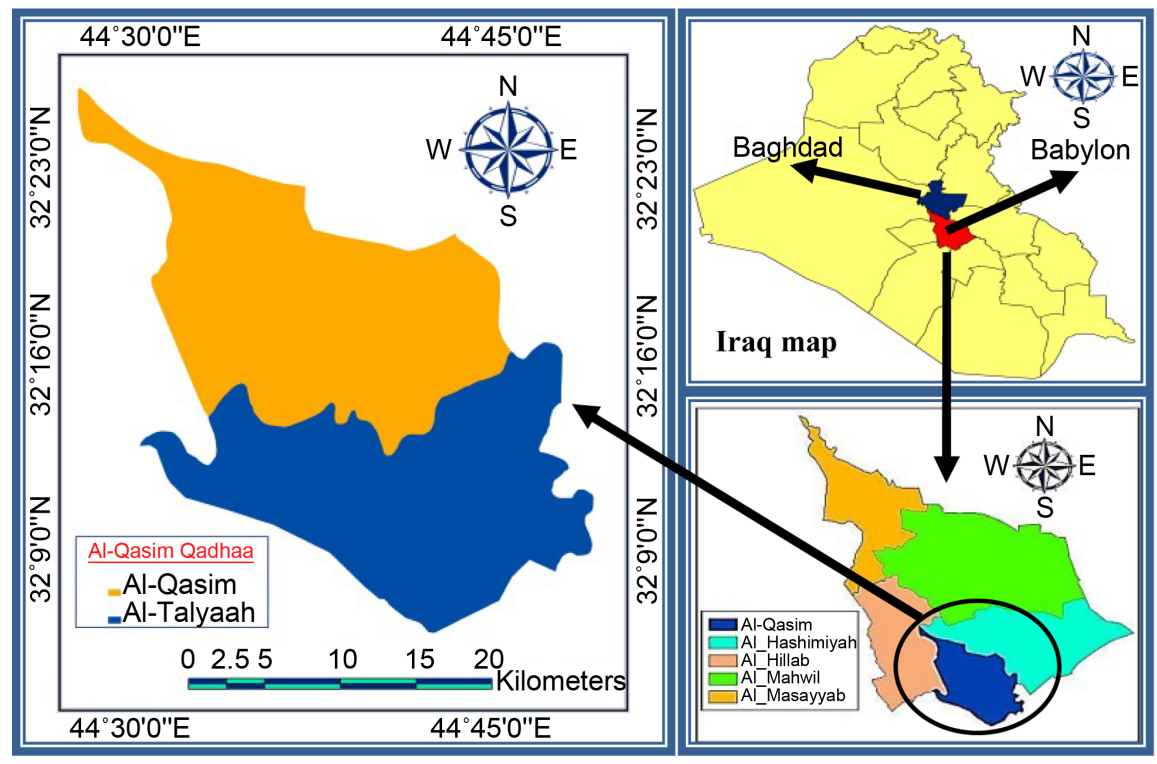

Figure 1. The study area across Al-Qasim Qadhaa, Babylon Governorate, Iraq. 
haeological sites of Iraq scale $(1: 1,500,000)$ [21] displays the important archaeological and religious sites in this Qadhaa.

\subsection{Preparing Rating Values for Sub-Criteria}

In this study, based on literature review and opinion of experts in this field, different requirements and regulations as well as available data about the study area, each criterion was classified into categories (sub-criteria), and each category was given a suitability rating value. In order to prepare each criterion and sub-criteria, there were a number of steps that were performed in GIS environment using special analysis tools (e.g., buffer, clip, extract, overlay, and map algebra, etc.) as shown in (Figure 2 \& Figure 3 ) and (Table 1 ).

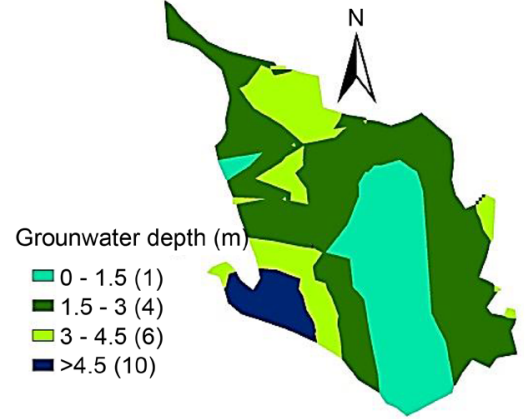

(a)

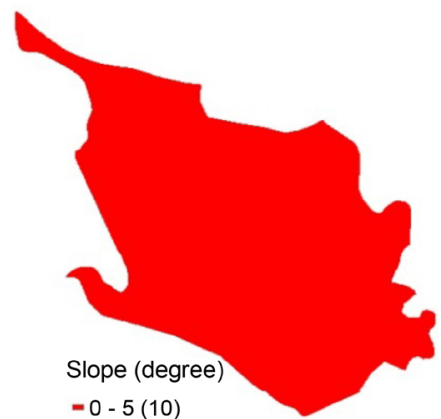

(d)

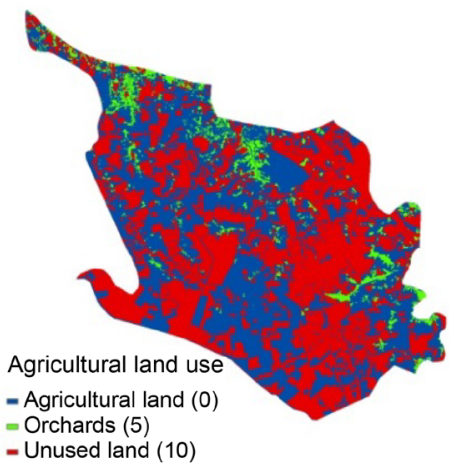

(g)

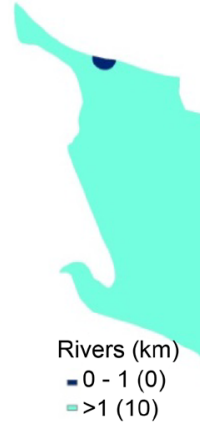

(b)

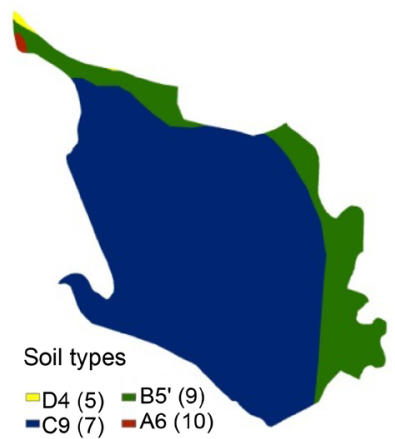

(e)

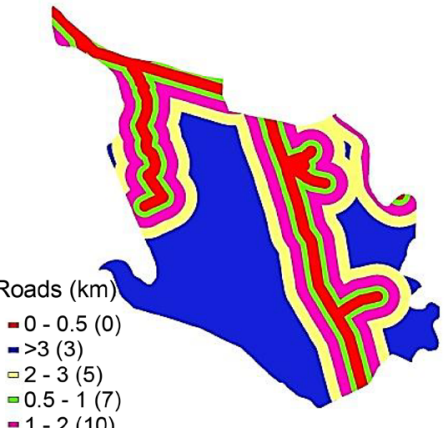

(h)

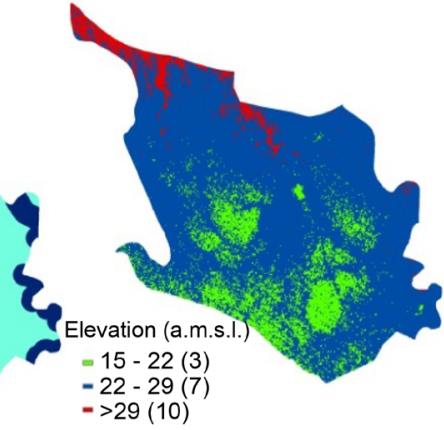

(c)

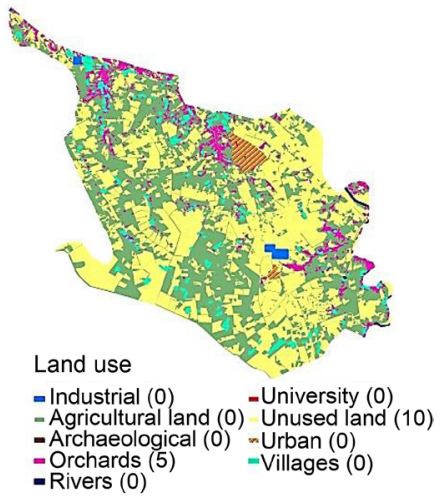

(f)

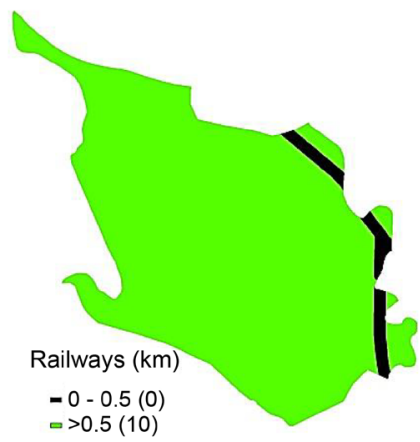

(i)

Figure 2. Maps of suitability indexes of (a): Ground water depth; (b): Rivers; (c): Elevation; (d): Slope; (e): Soil types; (f): Land use; (g): Agricultural land use; (h): Roads; (i): Railways. 


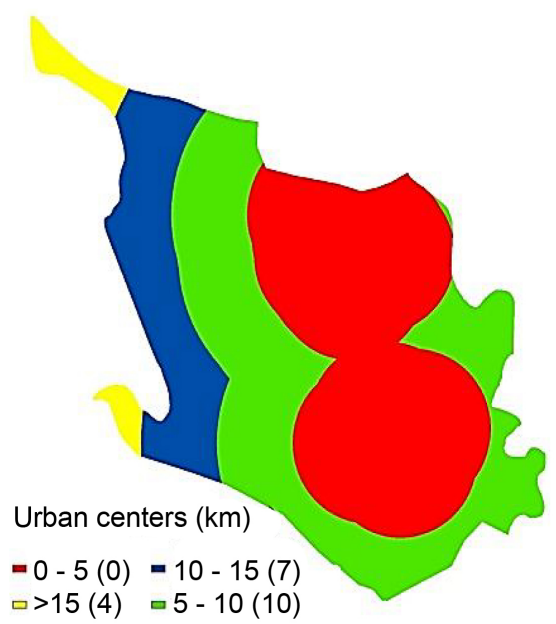

(a)

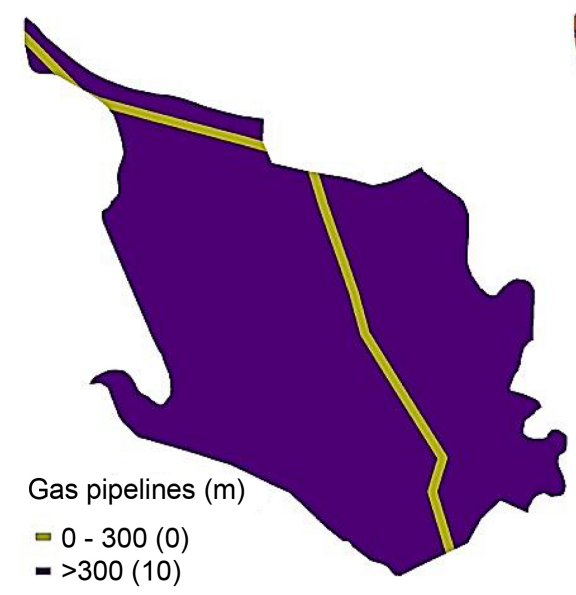

(d)

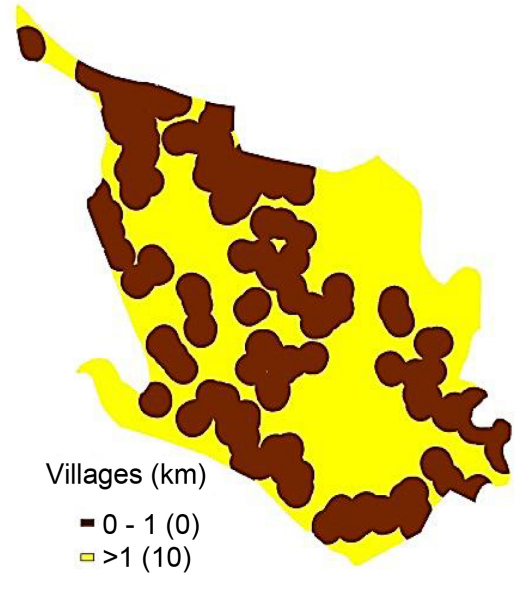

(b)

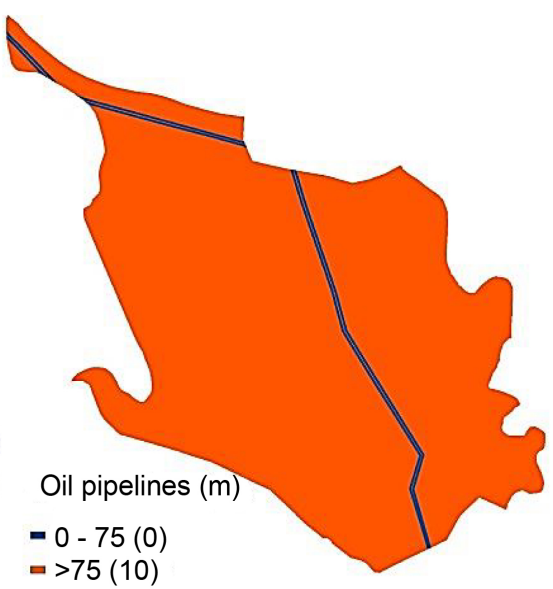

(e)

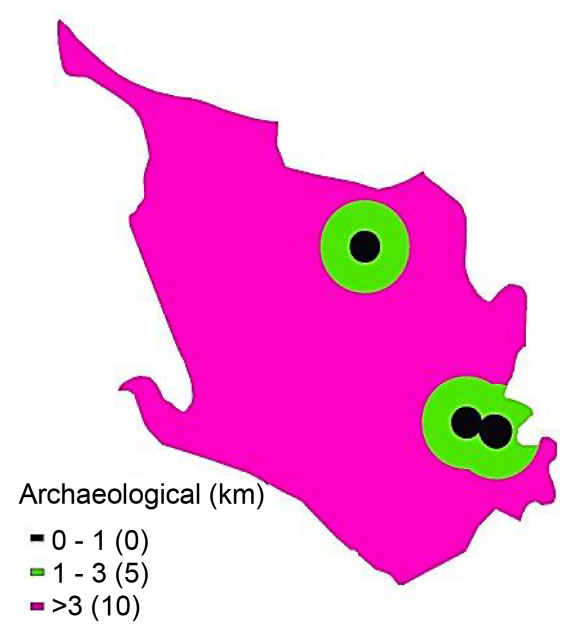

(c)

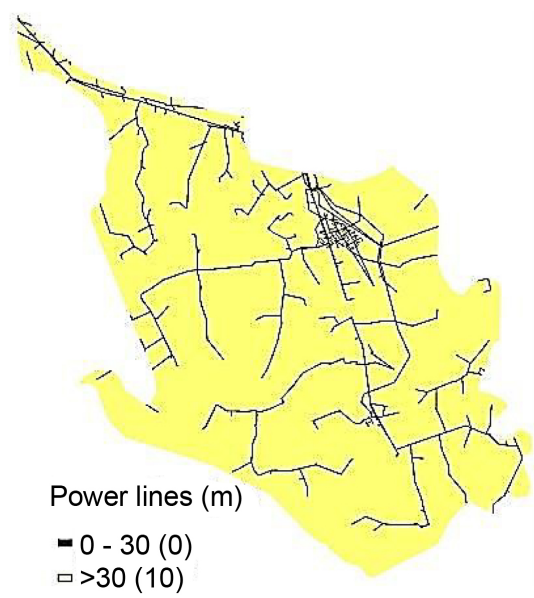

(f)

Figure 3. Maps of suitability indexes of (a): Urban centers; (b): Villages; (c): Archaeological sites; (d): Gas pipelines; (e): Oil pipelines and (f): Power lines.

\subsection{Multi-Criteria Decision Making Methods}

\subsubsection{Analytical Hierarchy Process (AHP)}

The Analytic Hierarchy Process (AHP) was developed by Thomas Saaty in 1980 to solve a complicated decision problem into simpler decision problems. AHP is used a matrix of pair wise comparison to derive the relative weights for criteria, rather than scoring weights directly, which used in other methods of Multi Criteria decision making. This method has high capability to assess the consistency of judgments, and mathematical foundation [22].

In the Analytic Hierarchy Process, the numerical scales of 9-points are used, where each point equates to an expression of the relative importance between each two criteria [12]. After selecting the number of all criteria ( $n$ ) for comparison purpose, AHP method was used the following steps to derive the weight for each criterion [23].

The typical matrix of the pair wise comparison $(A)$ for the criteria $(n \times m)$ was formed as follows: 
Table 1. The summary of the input layers used in the analysis.

\begin{tabular}{|c|c|c|c|}
\hline No. & Criteria & Sub-criteria Values & Sub-criteria Rating \\
\hline \multirow{4}{*}{1} & \multirow{4}{*}{ Groundwater depth (m) } & $0-1.5$ & 1 \\
\hline & & $1.5-3$ & 4 \\
\hline & & $3-4.5$ & 6 \\
\hline & & $>4.5$ & 10 \\
\hline \multirow{2}{*}{2} & \multirow{2}{*}{ Rivers $(\mathrm{km})$} & $0-1$ & 0 \\
\hline & & $>1$ & 10 \\
\hline \multirow{3}{*}{3} & \multirow{3}{*}{ Elevation (a.m.s.l.) } & $15-22$ & 3 \\
\hline & & $22-29$ & 7 \\
\hline & & $>29$ & 10 \\
\hline 4 & Slope (degree) & $0^{\circ}-5^{\circ}$ & 10 \\
\hline \multirow{4}{*}{5} & \multirow{4}{*}{ Soils types } & Soil 6 (A) & 10 \\
\hline & & Soil 5' (B) & 9 \\
\hline & & Soil 9 (C) & 7 \\
\hline & & Soil 4 (D) & 5 \\
\hline \multirow{9}{*}{6} & \multirow{9}{*}{ Land use } & Industrial area & 0 \\
\hline & & Urban centers & 0 \\
\hline & & Villages & 0 \\
\hline & & University & 0 \\
\hline & & Rivers & 0 \\
\hline & & Archaeological sites & 0 \\
\hline & & Agricultural lands & 0 \\
\hline & & Orchards & 5 \\
\hline & & Unused lands & 10 \\
\hline \multirow{3}{*}{7} & \multirow{3}{*}{ Agricultural land use } & Agricultural land & 0 \\
\hline & & Orchards & 5 \\
\hline & & Unused land & 10 \\
\hline \multirow{5}{*}{8} & \multirow{5}{*}{ Roads $(\mathrm{km})$} & $0-0.5$ & 0 \\
\hline & & $0.5-1$ & 7 \\
\hline & & $1-2$ & 10 \\
\hline & & $2-3$ & 5 \\
\hline & & $>3$ & 3 \\
\hline \multirow{2}{*}{9} & \multirow{2}{*}{ Railways (km) } & $0-0.5$ & 0 \\
\hline & & $>0.5$ & 10 \\
\hline \multirow{4}{*}{10} & \multirow{4}{*}{ Urban centers $(\mathrm{km})$} & $0-5$ & 0 \\
\hline & & $5-10$ & 10 \\
\hline & & $10-15$ & 7 \\
\hline & & $>15$ & 4 \\
\hline \multirow{2}{*}{11} & \multirow{2}{*}{ Villages $(\mathrm{km})$} & $0-1$ & 0 \\
\hline & & $>1$ & 10 \\
\hline
\end{tabular}




\section{Continued}

\begin{tabular}{|c|c|c|c|}
\hline \multirow{3}{*}{12} & \multirow{3}{*}{ Archaeological sites $(\mathrm{km})$} & $0-1$ & 0 \\
\hline & & $1-3$ & 5 \\
\hline & & $>3$ & 10 \\
\hline \multirow{2}{*}{13} & \multirow{2}{*}{ Gas pipelines $(\mathrm{m})$} & $\leq 300$ & 0 \\
\hline & & $>300$ & 10 \\
\hline \multirow{2}{*}{14} & \multirow{2}{*}{ Oil pipelines (m) } & $\leq 75$ & 0 \\
\hline & & $>75$ & 10 \\
\hline \multirow{2}{*}{15} & \multirow{2}{*}{ Power lines (m) } & $\leq 30$ & 0 \\
\hline & & $>30$ & 10 \\
\hline
\end{tabular}

$$
\left[\begin{array}{cccc}
a_{11} & a_{12} & \cdots & a_{1 n} \\
a_{21} & a_{22} & \cdots & a_{2 n} \\
\vdots & \vdots & \ddots & \vdots \\
a_{m 1} & a_{m 2} & \cdots & a_{m n}
\end{array}\right]
$$

The values of $a_{i j}$ is the element of row $(i=1,2, \cdots, m)$ and column $(j=1,2, \cdots, n)$, which are used to indicate the performance values in a matrix in terms of the $i$-th and $j$-th. The values of comparison criteria above the diagonal of the matrix were used to fill the upper triangular of the matrix. Then, the reciprocal values of the upper diagonal are used to fill the lower triangular of the matrix. This is performed by using the following formula: $\left(a_{j i}=1 / a_{i j}\right)$.

In order to normalize the matrix of pair wise comparison $\left(A_{v}\right)$, each value in column $(j)$ was divided by the summation values in column $(j)$ of the matrix, where the sum of each column should be equal to 1 . The new normalized matrix was created as follows.

$$
A_{v}=\left[\begin{array}{cccc}
\frac{a_{11}}{\sum a_{i 1}} & \frac{a_{12}}{\sum a_{i 2}} & \cdots & \frac{a_{1 n}}{\sum a_{i n}} \\
\vdots & \vdots & \ddots & \vdots \\
\vdots & \vdots & \ddots & \vdots \\
\frac{a_{m 1}}{\sum a_{i 1}} & \frac{a_{m 2}}{\sum a_{i 2}} & \cdots & \frac{a_{m n}}{\sum a_{i n}}
\end{array}\right]
$$

Then, the eigenvector was calculated as an average values in each row $\left(F_{i}\right)$ of the matrix $\left(A_{v}\right)$ to produce the matrix $\left(A_{f}\right)$; where $\left(F_{i}\right)$ is the value of relative importance (weight) of the ith criterion.

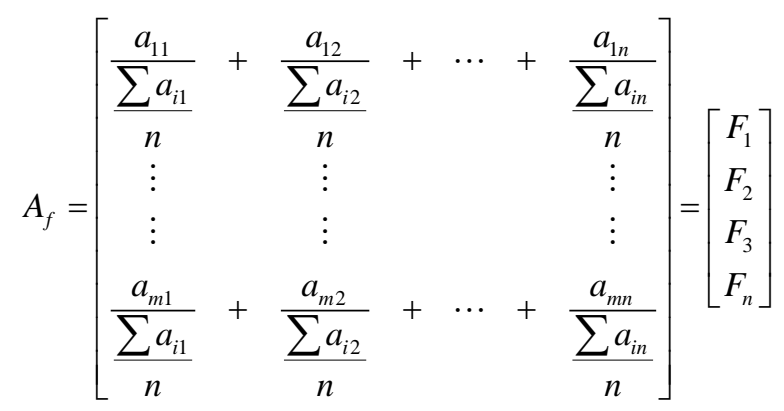


In order to calculate the consistency vector of the weight values $W_{p}$, this done by multiplying the matrix $\left(A_{v}\right)$ by the matrix $\left(A_{f}\right)$ which is considered the best estimation for the eigenvector as follow.

$$
A_{v} \times A_{f}=\left[\begin{array}{cccc}
a_{11} & a_{12} & \cdots & a_{1 n} \\
a_{21} & a_{22} & \cdots & a_{2 n} \\
\vdots & \vdots & \ddots & \vdots \\
a_{m 1} & a_{m 2} & \cdots & a_{m n}
\end{array}\right] \times\left[\begin{array}{c}
F_{1} \\
F_{2} \\
F_{3} \\
F_{n}
\end{array}\right]=\left[\begin{array}{c}
W_{1} \\
W_{2} \\
W_{3} \\
W_{n}
\end{array}\right]
$$

The eigenvalue of the pairwise comparison matrix $\left(\lambda_{\max }\right)$ was obtained from the following formula:

$$
\lambda_{\max }=\frac{1}{n} \sum_{i=1}^{n} \frac{W_{i}}{F_{i}}
$$

The consistency index (CI) is obtained by the following formula: $\mathrm{CI}=\left[\left(\lambda_{\max }-n\right) /(n-1)\right]$; where $n$ is the size of the matrix. In this study, $n=15$ and $\lambda_{\max }=15.58$; therefore $\mathrm{CI}=0.04$. The consistency ratio $(\mathrm{CR}=[(\mathrm{CI} / \mathrm{RI})])$ was determined depending on [12], through dividing the consistency index value $(\mathrm{CI})$ by the Random index value $(\mathrm{RI}=15.9)$ because the number of criteria was 15 [24] [25]. If the value of Consistency Ratio is smaller than 0.1, the ratio point to a reasonable consistency level in the pairwise comparison. In this study, the CR was equal to 0.026 lower than the critical limit of 0.1 . Figure 4 shows the matrix of pairwise comparison and the weights of criteria.

\subsubsection{Straight Rank Sum Method (SRS)}

The straight rank sum method (SRS) is a ranking method, and considered a simple method that uses to determine the weights of criteria through arranging the criteria according to relative importance from the most to the least signific-

\begin{tabular}{|c|c|c|c|c|c|c|c|c|c|c|c|c|c|c|c|c|}
\hline Criteria & 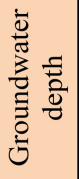 & 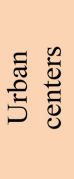 & 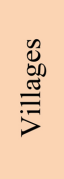 & $\begin{array}{l}\infty \\
\stackrel{0}{d} \\
\stackrel{2}{a}\end{array}$ & 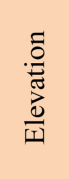 & $\frac{\check{0}}{\tilde{n}}$ & $\begin{array}{l}\frac{n}{\tilde{J}} \\
0 \\
0\end{array}$ & $\begin{array}{l}0 \\
0 \\
\vdots \\
0 \\
0 \\
0 \\
\infty\end{array}$ & 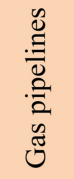 & $\begin{array}{l}\frac{\mathscr{E}}{\Xi} \\
\frac{0}{0} \\
\frac{0}{0}\end{array}$ & $\begin{array}{l}\mathscr{E} \\
\stackrel{\Xi}{\Xi} \\
\dot{0} \\
\vdots \\
0\end{array}$ & 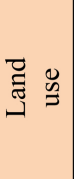 & 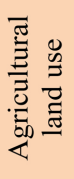 & 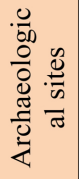 & 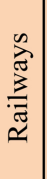 & 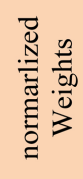 \\
\hline Groundwater depth & 1 & 2 & 3 & 2 & 4 & 5 & 5 & 4 & 8 & 8 & 7 & 6 & 5 & 6 & 9 & 0.2017 \\
\hline Urban centers & 0.50 & 1 & 2 & 1 & 3 & 4 & 4 & 3 & 7 & 7 & 6 & 5 & 4 & 5 & 8 & 0.1444 \\
\hline Rivers & 0.50 & 1.00 & 2.00 & 1 & 3 & 4 & 4 & 3 & 7 & 7 & 6 & 5 & 4 & 5 & 8 & 0.1444 \\
\hline Elevation & 0.25 & 0.33 & 0.50 & 0.33 & 1 & 2 & 2 & 1 & 5 & 5 & 4 & 3 & 2 & 3 & 6 & 0.0705 \\
\hline Slope & 0.20 & 0.25 & 0.33 & 0.25 & 050 & 1 & 1 & 0.5 & 4 & 4 & 3 & 2 & 1 & 2 & 5 & 0.0469 \\
\hline Roads & 0.20 & 0.25 & 0.33 & 0.25 & 0.50 & 1.00 & 1 & 0.5 & 4 & 4 & 3 & 2 & 1 & 2 & 5 & 0.0469 \\
\hline Soils types & 0.25 & 0.33 & 0.50 & 0.33 & 1.00 & 2.00 & 2.00 & 1 & 5 & 5 & 4 & 3 & 2 & 3 & 6 & 0.0705 \\
\hline Gas pipelines & 0.13 & 0.14 & 0.17 & 0.14 & 0.20 & 0.25 & 0.25 & 0.20 & 1 & 1 & 0.5 & 0.34 & 0.25 & 0.34 & 2 & 0.0152 \\
\hline Oil pipelines & 0.13 & 0.14 & 0.17 & 0.14 & 0.20 & 0.25 & 0.25 & 0.20 & 1.00 & 1 & 0.5 & 0.34 & 0.25 & 0.34 & 2 & 0.0152 \\
\hline Land use & 0.17 & 0.20 & 0.25 & 0.20 & 0.33 & 0.50 & 0.50 & 0.33 & 2.94 & 2.94 & 2.00 & 1 & 0.5 & 1 & 4 & 0.0312 \\
\hline Agricultural land use & 0.20 & 0.25 & 0.33 & 0.25 & 0.50 & 1.00 & 1.00 & 0.50 & 4.00 & 4.00 & 2.94 & 2.00 & 1 & 2 & 5 & 0.0468 \\
\hline Archaeological sites & 0.17 & 0.20 & 0.25 & 0.20 & 0.33 & 0.50 & 0.50 & 0.33 & 2.94 & 2.94 & 2.00 & 1.00 & 0.50 & 1 & 4 & 0.0312 \\
\hline Railways & 0.11 & 0.13 & 0.14 & 0.13 & 0.17 & 0.20 & 0.20 & 0.17 & 0.50 & 0.50 & 0.33 & 0.25 & 0.20 & 0.25 & 1 & 0.0113 \\
\hline
\end{tabular}
ance depending on the literature review and preference of decision makers using

Figure 4. Pairwise comparisons matrix and the weights of criteria for selecting suitable landfill site using AHP method. 
the following formula $\left(n-r_{i}+1\right)$. Then the weights of criteria are normalized through dividing each weight of criterion by their sum $\sum\left(n-r_{g}+1\right)$ (Table 2) according to Equation (2) [13] (Table 2):

$$
W_{i}=\left(n-r_{i}+1\right) / \sum\left(n-r_{g}+1\right)
$$

where, $W_{i}$ is the relative importance of normalized weight for ith criterion; $n$ is the number of criteria in this study under consideration $(g=1,2, \cdots, n) ; r_{i}$ is the position of rank for the factor.

\section{Results and Discussion}

\subsection{Final Output Maps}

After determining the weights for each criterion using the AHP and SRS methods, suitable ratings for the sub-criteria of each criterion were assigned based on the previous studies in this field and experts opinion. The weighted liner combination (WLC) method was applied on all criteria using special analysis tool "Map Algebra" to obtain the final output map of the suitability index for a landfill siting in Al-Qasim Qadhaa. The WLC method was applied depending on the following Equation (3):

$$
Y=\sum_{j=1}^{n} W_{j} \times K_{i j}
$$

where, $Y_{i}$ is the suitability index for area $i, W_{j}$ is the relative importance weighting of the criterion, $K_{i j}$ is the grading value of area $i$ under criterion $j$, and $n$ is the

Table 2. The criterion weightings defined for the Straight Rank Sum (SRS) method and Normalized weight.

\begin{tabular}{cccc}
\hline No. & Criterion & $\begin{array}{c}\text { Criteria weight } \\
\left(n-r_{i}+1\right)\end{array}$ & $\begin{array}{c}\text { Normalized weights } \\
W_{i}=\left(n-r_{i}+1\right) / \sum\left(n-r_{g}+1\right)\end{array}$ \\
\hline 1 & Groundwater depth & 10 & 0.111 \\
2 & Urban centers & 9 & 0.1 \\
3 & Rivers & 9 & 0.1 \\
4 & Villages & 8 & 0.089 \\
5 & Elevation & 7 & 0.078 \\
6 & Soils types & 7 & 0.078 \\
7 & Slope & 6 & 0.067 \\
8 & Roads & 6 & 0.067 \\
9 & Agricultural land use & 6 & 0.067 \\
10 & Land use & 5 & 0.056 \\
11 & Archaeological sites & 5 & 0.056 \\
12 & Power lines & 4 & 0.044 \\
13 & Gas pipelines & 3 & 0.033 \\
14 & Oil pipelines & 3 & 0.033 \\
15 & Railways & 2 & 0.022 \\
& Sum & 90 & 1 \\
\hline
\end{tabular}


total number of criteria [26] [7].

The summary of criteria weights which were computed using the methods of AHP and SRS can be seen in Table 3.

Each final map was divided into four categories are: unsuitable areas, moderately suitable areas, suitable areas and most suitable areas (Figure 5(a) and Figure 5(b)). Table 4 shows the area for each category and its proportion of the total study area that resulted from the two methods.

\subsection{Comparison of the Two Final Raster Maps Using the Change Detection Method Some Common Mistakes}

For comparing the resultant maps which were produced from using the two methods (AHP and SRS) in Al-Qasim Qadhaa, these raster maps were classified into four categories separately. The fourth categories are: 1) unsuitable areas, 2)

Table 3. The summary of criteria weights that resulted from using AHP and SRS methods.

\begin{tabular}{lccc}
\hline No. & Criterion & AHP & SRS \\
\hline 1 & Groundwater depth & 0.2017 & 0.111 \\
2 & Urban centers & 0.1444 & 0.1 \\
3 & Rivers & 0.1444 & 0.1 \\
4 & Villages & 0.1021 & 0.089 \\
5 & Elevation & 0.0705 & 0.078 \\
6 & Soils types & 0.0705 & 0.078 \\
7 & Slope & 0.0469 & 0.067 \\
8 & Roads & 0.0469 & 0.067 \\
9 & Agricultural land use & 0.0468 & 0.067 \\
10 & Land use & 0.0312 & 0.056 \\
11 & Archaeological sites & 0.0312 & 0.056 \\
12 & Power lines & 0.0217 & 0.044 \\
13 & Gas pipelines & 0.0152 & 0.033 \\
14 & Oil pipelines & 0.0152 & 0.033 \\
15 & Railways & 0.0113 & 0.022 \\
& Sum & 1 & 1 \\
\hline
\end{tabular}

Table 4. The area of each category and its proportion for the final maps using the two methods.

\begin{tabular}{ccccc}
\hline \multirow{2}{*}{ Category } & \multicolumn{2}{c}{ AHP method } & \multicolumn{2}{c}{ SRS method } \\
\cline { 2 - 5 } & Area $\left(\mathrm{km}^{2}\right)$ & Proportion \% & Area $\left(\mathrm{km}^{2}\right)$ & Proportion \% \\
\hline 1 & 46.30 & 7.98 & 23.40 & 4.03 \\
2 & 239.18 & 41.2 & 185.66 & 31.98 \\
3 & 220.92 & 38.06 & 292.70 & 50.43 \\
4 & 74.10 & 12.76 & 78.72 & 13.56 \\
\hline
\end{tabular}




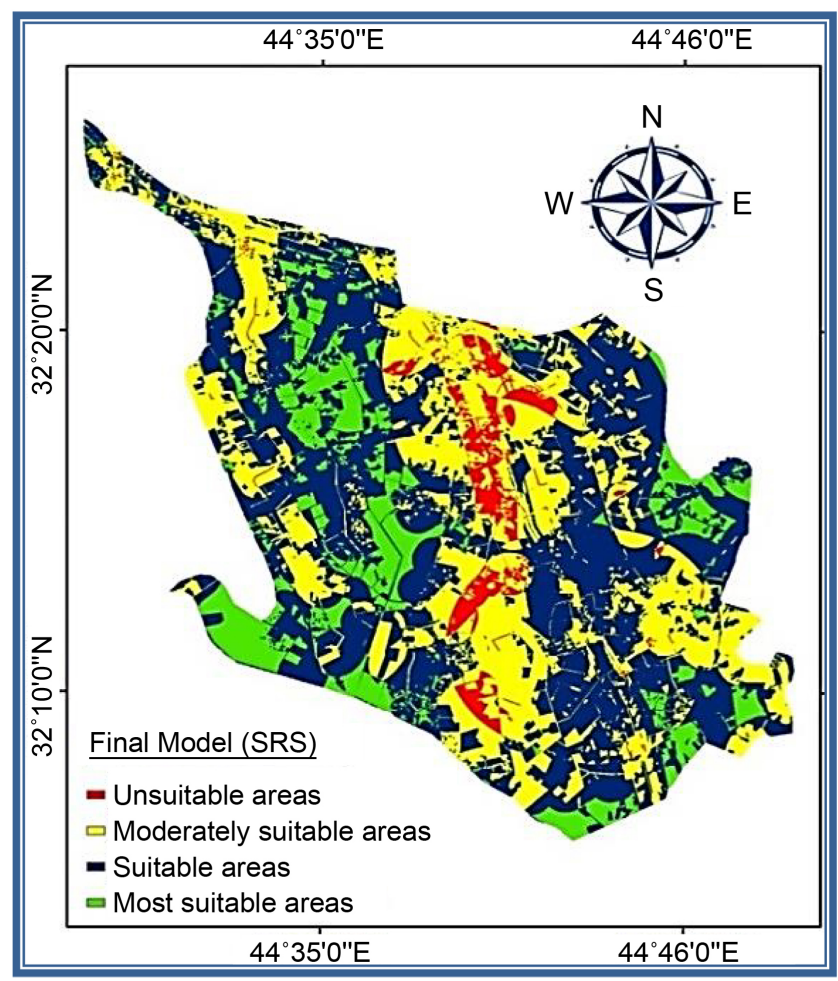

(a)

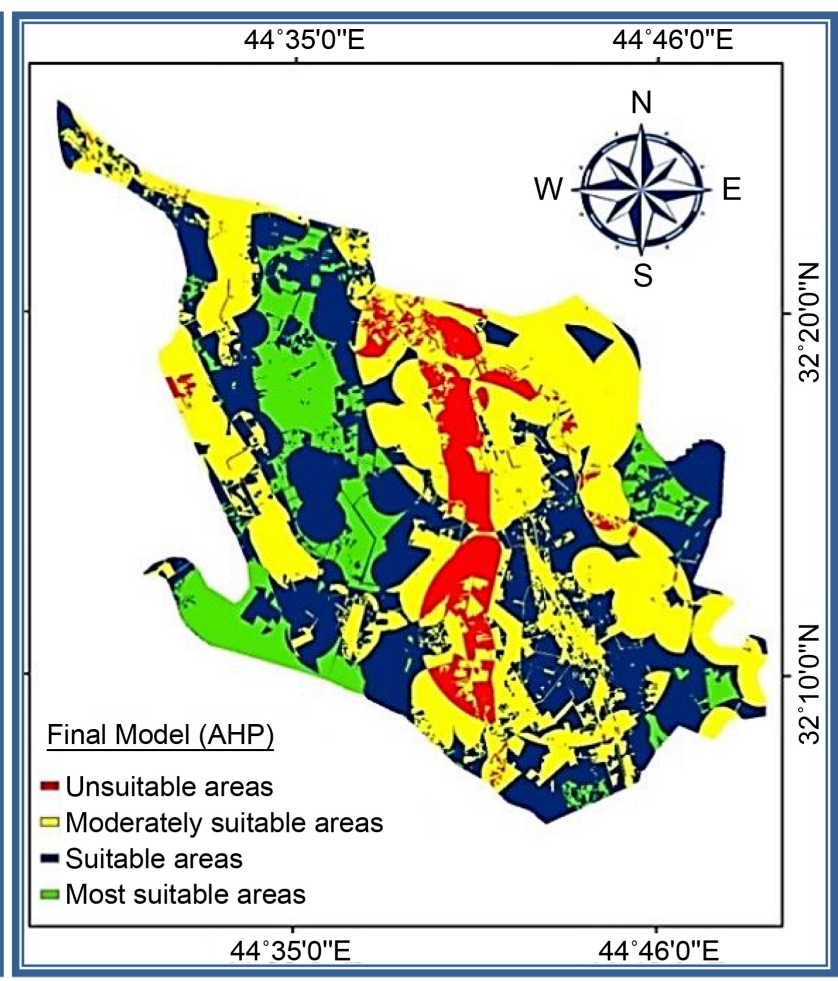

(b)

Figure 5. Map of suitability index for landfill sites using (a) AHP model (b) SRS model.

moderately suitable areas, 3) suitable areas and 4) most suitable areas.

The Change Detection method was introduced by the U.S. National Land Cover Database (NLCD) [27], and it was used to compare the pixels of two maps (images) in the same area. The Change Detection method is usually used in many remote-sensing applications

(http://digitalcommons.unl.edu/cgi/viewcontent.cgi?article=1720\&context $=$ usgs staffpub).

In this study, this method was used to compare the final raster maps for each category, which were entered in GIS using the spatial analysis tool "Map Algebra" by applying the formula "(AHP raster map) Diff (SRS raster map)". Consequently, the comparison process was used to determine and check the suitability of the selected sites for landfill on both resulted maps from the two methods.

The resultant compression map was classified into matching areas and nonmatching areas, as shown in Table 5. The proportion of matching pixels in comparison map was $75.35 \%$ (in blue), whilst the proportion of the non-matching pixels for all categories was $24.65 \%$ (Red) (Figure 6).

\subsection{Obtaining of Candidate Sites}

The solid waste quantity expected in 2030 in Al-Qasim Qadhaa is 76,374 tonnes. The cumulative quantity of solid waste expected from 2020 to 2030 is 695,219 tonnes based on an expected population in 2030 in this Qadhaa of 304,621 inhabitants, according to calculations made by [28]. The density of waste in waste 
Table 5. The results of comparison two maps resulted from (AHP) and (SRS) methods.

\begin{tabular}{cccccc}
\hline Value & Count & categories (AHP) & categories (SRS) & $\begin{array}{c}\text { Corresponding } \\
\text { pixels ratios }\end{array}$ & Classification \\
\hline 1 & 699,926 & All categories & All categories & 75.35 & Matching \\
2 & 37,187 & (US) 1 & (US) 1 & 4 & Non-matching \\
3 & 131,624 & (MOS) 2 & (MOS) 2 & 14.17 & Non-matching \\
4 & 38,297 & (S) 3 & (S) 3 & 4.12 & Non-matching \\
5 & 21,848 & (MS) 4 & (MS) 4 & 2.36 & Non-matching \\
\hline
\end{tabular}

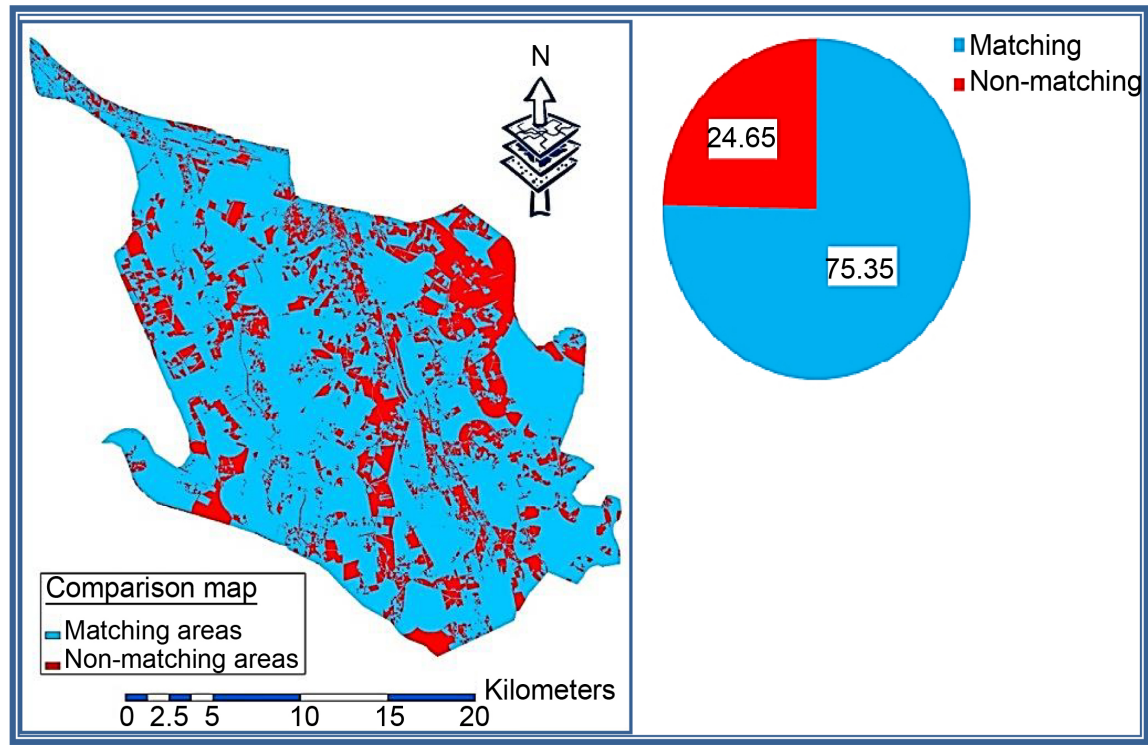

Figure 6. The comparison map between AHP and SRS methods using Change Detection method.

disposal sites is $450 \mathrm{~kg} / \mathrm{m}^{3}$ in Al-Qasim Qadhaa [29]. By dividing the solid waste quantity over the density of waste, the expected volume of waste and the predictable volume of cumulative waste in 2030 are $169,720 \mathrm{~m}^{3}$ and $1,544,931 \mathrm{~m}^{3}$, respectively. Two meters height was assumed for the compacted waste in the candidate sites for landfill in Al-Qasim Qadhaa. Therefore, the required area of a candidate site to accommodate the cumulative quantity of solid waste generated from 2020 to 2030 is $0.772 \mathrm{~km}^{2}$.

Two candidate sites were selected for landfill among the many sites located within the category of the "most suitable" index. These sites were each assigned a number ( 1 and 2). The area of Site No. 1 is $2.766 \mathrm{~km}^{2}$, while the area of Site No. 2 is $2.055 \mathrm{~km}^{2}$. These candidate sites are suitable for landfill in Al-Qasim Qadhaa. Site No.1 is situated at latitude $32^{\circ} 11^{\prime} 43^{\prime \prime} \mathrm{N}$, and longitude $44^{\circ} 32^{\prime} 26^{\prime \prime} \mathrm{E}$, while the site. No. 2 is situated at latitude $32^{\circ} 14^{\prime} 38^{\prime \prime} \mathrm{N}$, and longitude $44^{\circ} 37^{\prime} 10^{\prime \prime} \mathrm{E}$. These sites were checked on the satellite images (2011) of the Babylon Governorate to make sure that these sites were suitable for landfill (Figure 7). 


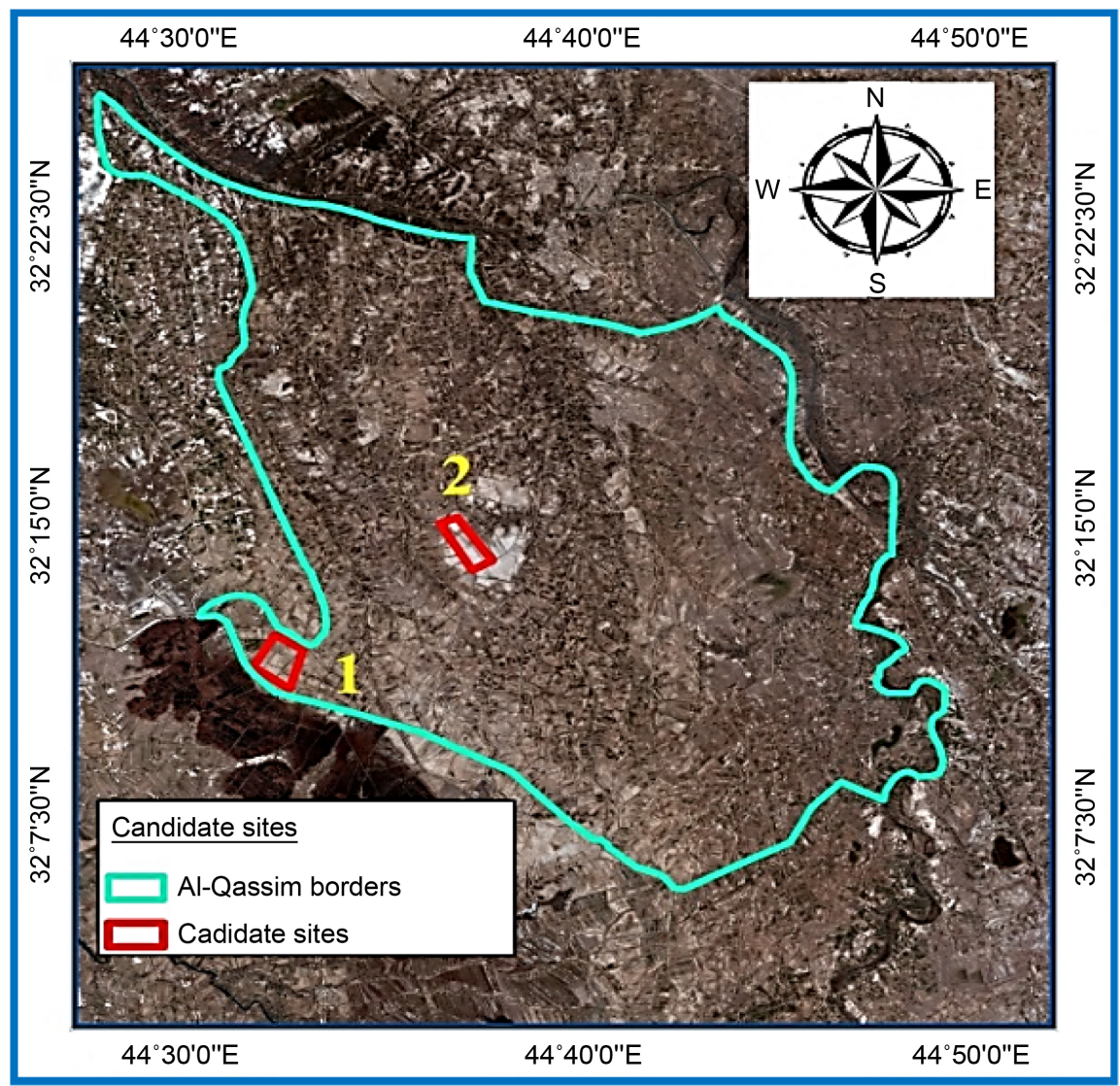

Figure 7. Landfill sites map for Al-Qasim Qadhaa.

\section{Conclusions}

This study aimed to select suitable sites for landfill in Al-Qasim Qadhaa using the best methodology and also by taking into account the scientific and environmental criteria which are followed in advanced countries. In order to determine the most suitable site for solid waste landfill in Al-Qasim Qadhaa, 15 layers were incorporated in the process of analysis using GIS software, where the GIS is considered a powerful tool for assisting in the selection of a site for landfill due to its ability to deal with a large volume of data from different sources. These layers were: groundwater depth, urban centers, rivers, villages, soil types, elevation, roads agricultural land use, slope, land use, archaeological sites, power lines, gas pipelines, oil pipelines and railways.

Two methods (AHP and SRS) were applied to derive the weights of criteria using different styles. The AHP is a pair-wise comparisons, while the SRS is considered a ranking method, where these methods represented the types of multi-criteria decision making methods. Then, WLC method was used to produce a suitability index for the final output map for the study area. This map was divided into four categories (unsuitable areas, moderately suitable areas, suitable areas and most suitable areas).

The method of Change Detection was used to compare the whole pixels for the four categories of the two maps that resulted from the two methods (AHP 
and SRS). In the resultant comparison map, the proportion value of matching pixels was $75.35 \%$, while the non-matching pixels were $24.65 \%$

Finally, in the category of "most suitable" on the final map, two candidate sites were identified for landfill among several sites. The area of Sites No. 1 and No. 2 are 2.766 and $2.055 \mathrm{~km}^{2}$, respectively. The required area in the present study that can well accommodate such waste was $0.772 \mathrm{~km}^{2}$.

\section{References}

[1] Alavi, M.R., Mokhtarani, N. and Mokhtarani, B. (2009) Municipal Solid Waste Management in Rasht City, Iran. Waste Management, 29, 485-489.

https://doi.org/10.1016/j.wasman.2008.02.029

[2] Moeinaddini, M., Khorasani, N., Danehkar, A., Darvishsefat, A.A. and Zienalyan, M. (2010) Siting MSW Landfill Using Weighted Linear Combination and Analytical Hierarchy Process (AHP) Methodology in GIS Environment (Case Study: Karaj). Waste Management, 30, 912-920. https://doi.org/10.1016/j.wasman.2010.01.015

[3] Kim, K.R. and Owens, G. (2010) Potential for Enhanced Phytoremediation of Landfills Using Biosolids: A Review. Journal of Environmental Management, 91, 791-7. https://doi.org/10.1016/j.jenvman.2009.10.017

[4] Brockerhoff, M. (2000) An Urbanizing World. Population Reference Bureau, 55, $1-46$.

[5] Proske, H., Vlcko, J., Rosenbaum, M.S., Dorn, M., Culshaw, M. and Marker, B. (2005) Special Purpose Mapping for Waste Disposal Sites. Bull Engineering Geology Environment, 64, 1-54. https://doi.org/10.1007/s10064-004-0261-6

[6] Nas, B., Cay, T., Iscan, F. and Berktay, A. (2010) Selection of MSW Landfill Site for Konya, Turkey Using GIS and Multi-criteria Evaluation. Environmental Monitoring and Assessment, 160, 491-500. https://doi.org/10.1007/s10661-008-0713-8

[7] Eskandari, M., Homaee, M. and Mahmodi, S. (2012) An Integrated Multi Criteria Approach for Landfill Siting in a Conflicting Environmental, Economical and Socio-Cultural Area. Waste Management, 32, 1528-1538.

https://doi.org/10.1016/j.wasman.2012.03.014

[8] Lin, H. and Kao, J. (1999) Enhanced Spatial Model for Landfill Siting Analysis. Journal of Environmental Engineering, 125, 845-851. https://doi.org/10.1061/(ASCE)0733-9372(1999)125:9(845)

[9] Javaheri, H., Nasrabadi, T., Jafarian, M.H., Rowshan, G.R. and Khoshnam, H. (2006) Site Selection of Municipal Solid Waste Landfills Using Analytical Hierarchy Process Method in a Geographical Information Technology Environment in Giroft. Journal of Environmental Health Science \& Engineering, 3, 177-184.

[10] Kontos, T.D., Komilis, D.P. and Halvadakis, C.P. (2003) Siting MSW Landfills on Lesvos Island with a GIS Based Methodology. Waste Management \& Research, 21, 262-277. https://doi.org/10.1177/0734242X0302100310

[11] Delgado, O.B., Mendoza, M., Granados, E.L. and Geneletti, D. (2008) Analysis of Land Suitability for the Siting of Inter-Municipal Landfills in the Cuitzeo Lake Basin, Mexico. Waste Management, 28, 1137-1146. https://doi.org/10.1016/j.wasman.2007.07.002

[12] Saaty, T.L. (1980) The Analytic Hierarchy Process: Planning, Priority Setting, Resources Allocation. McGraw, New York.

[13] Malczewski, J.A. (1999) GIS and Multi Criteria Decision Analysis. John Wiley \& 
Sons, New York, 392 p.

[14] Iraqi Ministry of Municipalities and Public Works (2009) Structural Plan of Babylon Governorate. Iraqi Ministry of Municipalities and Public Works, Baghdad.

[15] Iraqi Ministry of Planning (2016) Records of Directorate of Census Babylon. Iraqi Ministry of Planning, Baghdad.

[16] Iraqi Ministry of Education (2015) Data of the Directorate General. Internal Reports, The Department of Scientific Affairs, Baghdad.

[17] Iraqi Ministry of Water Resources (2015) General Commission for Groundwater. Internal Reports, Iraqi Ministry of Water Resources, Baghdad.

[18] Iraqi Ministry of Water Resources (1990) State Commission of Survey. Internal Reports, Iraqi Ministry of Water Resources, Baghdad.

[19] Iraqi Ministry of Municipalities and Public Works (2011) Directorate of Sewage Babylon. Internal Reports, Iraqi Ministry of Municipalities and Public Works, Baghdad.

[20] Buringh, P. (1960) Soils and Soil Conditions in Iraq, Baghdad. The Ministry of Agriculture, Iraq, 337.

[21] World Digital Library (2013) The Archaeological Map of Iraq. https://www.wdl.org/en/item/212/view/1/1/ https://www.wdl.org/en/item/212/

[22] Teknomo, K. (2006) Analytic Hierarchy Process (AHP) Tutorial. Revoledu.com. http://people.revoledu.com/kardi/tutorial/AHP/Multi-Criteria-Decision-Making.ht $\underline{\mathrm{m}}$ http://people.revoledu.com/kardi/tutorial/AHP/

[23] Uyan, M. (2014) MSW Landfill Site Selection by Combining AHP with GIS for Konya, Turkey. Environmental Earth Sciences, 71, 1629-1639. https://doi.org/10.1007/s12665-013-2567-9

[24] Chang, C., Wu, C., Lin, C. and Lin, H.L. (2007) Evaluating Digital Video Recorder Systems Using Analytic Hierarchy and Analytic Network Processes. Information Sciences, 177, 3383-3396. https://doi.org/10.1016/j.ins.2007.02.010

[25] Isalou, A., Zamani, V., Shahmoradi, B. and Alizadeh, H. (2013) Landfill Site Selection Using Integrated Fuzzy Logic and Analytic Network Process (F-ANP). Environmental Earth Sciences, 68, 1745-1755. https://doi.org/10.1007/s12665-012-1865-y

[26] El Alfy Z., Elhadary R. and Elashry A. (2010) Integrating GIS and MCDM to Deal with Landfill Site Selection. International Journal of Engineering \& Technology, 10, $32-42$.

[27] Jin, S., Yang, L., Danielson, P., Homer, C., Fry, J. and Xian, G. (2013) A Comprehensive Change Detection Method for Updating the National Land Cover Database to Circa 2011. Remote Sensing of Environment, 132, 159-175. https://doi.org/10.1016/j.rse.2013.01.012

[28] Chabuk, A., Al-Ansari, N., Hussain, H.M., Knutsson, S. and Pusch, R. (2015) Present Status of Solid Waste Management at Babylon Governorate, Iraq. Engineering, 7, 408-423. https://doi.org/10.4236/eng.2015.77037

[29] Iraqi Ministry of Municipalities and Public Works (2015) Records of Directorate of Babylon Municipalities, Babylon. Iraqi Ministry of Municipalities and Public Works, Baghdad. 
Submit or recommend next manuscript to SCIRP and we will provide best service for you:

Accepting pre-submission inquiries through Email, Facebook, LinkedIn, Twitter, etc. A wide selection of journals (inclusive of 9 subjects, more than 200 journals)

Providing 24-hour high-quality service

User-friendly online submission system

Fair and swift peer-review system

Efficient typesetting and proofreading procedure

Display of the result of downloads and visits, as well as the number of cited articles Maximum dissemination of your research work

Submit your manuscript at: http://papersubmission.scirp.org/

Or contact eng@scirp.org 